Editorial

\title{
No albino should suffer from extensive skin cancers let alone die there-from
}

\begin{abstract}
The epidemiology of albino skin cancer in Nigeria was reported in 1977. Since then, a major issue has been the late presentation of albinos for treatment. In general, the woeful picture of cancer in man led a US President to declare war on it. Incidentally, a contributor who had such a war in mind, lamented that "Too many adults still die from common epithelial cancers." In this context, let me add my personal experience of the albino skin cancer variety in the Nigerian community, where the Igbo Ethnic Group warrants being used to hypothesize that no albino should suffer from extensive skin cancer let alone die of it. In principle, emphasis should be led on
\end{abstract}

i. The expert mother care of the affected children;

ii. The planned education of the public;

iii. The promotion of this mundane matter through the rising women empowerment groups; and

iv. The employment statutorily of all victims indoors. In conclusion, the hitherto prevailing sheer horror of albinism is contrastable with my personal experience of 2 albino medical students, who subsequently became consultant physicians with unblemished faces! This should, in short, be a world-wide goal.
Volume 2 Issue 3 - 2015

Wilson Onuigbo
Medical Foundation and Clinic, Nigeria

Correspondence: Wilson Onuigbo, Medical Foundation and Clinic, 8 Nsukka Lane, Enugu 40000I, Nigeria, Tel 2348037208680, Email Wilson.onuigbo@gmail.com

Received: March 3I, 2015 | Published: April 07, 2015

Keywords: albino, skin cancer, prevention, morbidity, fatality, public policy

\section{Editorial}

Goal of the epidemiological type was achieved as far back as 1977 by Okoro, ${ }^{1}$ who surveyed the incidence of albinism in Nigeria. Today, the problem is that the sufferers arrive at the hospitals for treatment very late. ${ }^{2,3}$ Fortunately, my position as a Visiting Surgical Pathologist in a Hospital having a Plastic Surgery Department facilitated the documentations of the tragic albino pictures ${ }^{4-7}$ Pictures of this calamity are, as I have painted them, with reference to the measurements in $\mathrm{cm}$ of the surgical biopsies taken from 263 albinos of the Igbo Ethnic Group domiciled in the South Eastern Region of Nigeria. ${ }^{8}$ Note that the panorama is manifested in the subjoined (Table 1).

Table I Measurements in $\mathrm{cm}$ of 263 excised albino skin cancers

\begin{tabular}{lll}
\hline Extent $\mathbf{( c m )}$ & No. & $\%$ \\
\hline $\mathrm{I}$ & 10 & 3.4 \\
2 & 27 & 10.2 \\
3 & 41 & 15.6 \\
4 & 55 & 20.9 \\
$5+$ & 130 & 49.9 \\
Total & 263 & 100 \\
\hline
\end{tabular}

Surely, these figures do speak loudly for only $3.4 \%$ of the cohort presenting as $1 \mathrm{~cm}$ lesions, whereas $49.9 \%$ measured $5 \mathrm{~cm}$ or more. No wonder that, even the ear and the eye, may be sacrificed during the necessitated heroic surgery (Figure $1 \& 2$ ).

Accordingly, let me advance the hypothesis that no albino should ever suffer from gargantuan lesions let alone die there from! Firstly, the mothers themselves must muster care in their home surroundings. Secondly, public health education must be intensified. Thirdly, the rising women empowerment movements ought to take up the cudgels in this meritorious matter. Finally, the Government itself must ensure the automatic employment of these victims indoors as a matter of statutory policy.

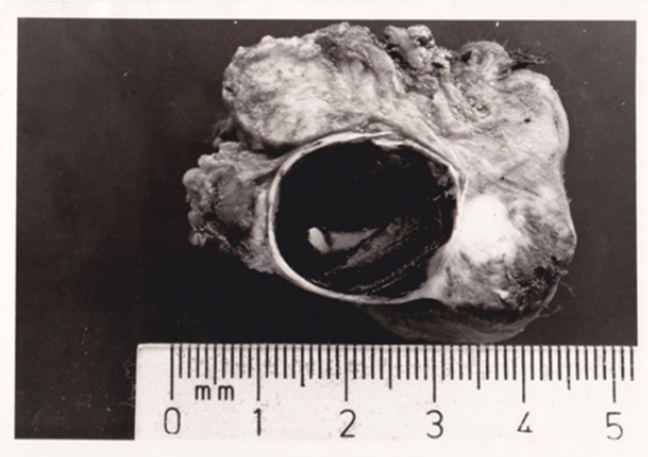

Figure I Surgical specimen showing the eyeball as the casualty.

Policy of note came not long ago from a US President concerning "The War on Cancer." Actually, as Sporn" lamented, "Too many adults still die from common epithelial cancers." Consequently, the thrust of the present paper is that, indeed, not a single albino should even come to serious grief let alone die of cancer of the skin. This will certainly materialize if the above documented surveillance options are firmly rooted right from childhood. In particular, the Government's policy option should guarantee the indoor employment of the disadvantaged albinos. Indeed, I am persuaded, after fortunately teaching 2 female medical students, who eventually became Consultant Physicians with unblemished faces that the present proposal is not a figment of imagination but a pillar to lean on while advancing this preventive cancer research! 


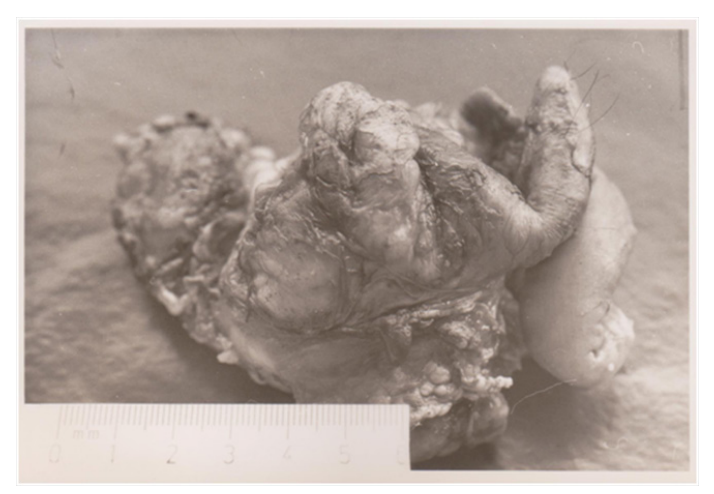

Figure 2 Surgical specimen showing cancer sparing an albino's pinna, although the whole ear had to be sacrificed during heroic surgery.

\section{Acknowledgments}

None.

\section{Conflicts of interest}

Author declares that there is no conflict of interest.

\section{References}

1. Okoro AN. Albinism in Nigeria. A clinical and social study. $B r J$ Dermatol. 1975;92(5):485-492.

2. Asuquo ME, Ngim O, Ebughe G, et al. Skin cancers amongst four Nigerian albinos. Int J Dermatol. 2009;48(6):636-638.

3. Yakubu A, Mabogunje OA. Skin cancer in African albinos. Acta Oncol. 1993;32(6):621-622.

4. Onuigbo WIB. Comparative study of squamous cell carcinoma of the eyelids in blacks and albinos. Int J Ophthalmol. 2005;5(5):836-837.

5. Onuigbo WIB, Nnabuko RE. Three different carcinomas clustered in one facial focus in albino. Nig J Surg Sci. 2009;19:38-40.

6. Onuigbo WIB, Achebe JU. Eyelid cancer in an albino that progressed to exenteration indicates the failure of public health education in Nigerian community. Int J Opthamol; 2014

7. Onuigbo WIB, Nwozo JC, Nnabuko RE. Rhabdomyosarcoma followed six episodes of squamous cell carcinoma in a Nigerian albino: A case report. Int J Med \& Med Sci. 2014;6(11):236-238.

8. Basden GT. Niger Ibos. London Cass; 1966.

9. Sporn MB. The war on cancer. Lancet. 1996;347(9012):1377-1381. 